\title{
The Double Bind: The Politics of Racial and Class Inequalities in the Americas Executive Summary
}

\author{
Juliet Hooker, University of Texas, Austin \\ Alvin B. Tillery, Jr., Northwestern University
}

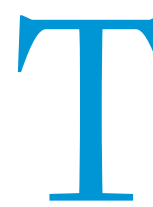

his report summarizes the work of the American Political Science Association's Presidential Task Force on Racial and Class Inequalities in the Americas. The main goal of the task force was to investigate the relationship between race and class in producing material, political, and social inequalities in the nations of the Americas. The task force also examined how the political systems in these countries work to foment and/or ameliorate inequalities that track with ethnic and racial identities and socioeconomic status.

Clearly, enormous diversity exists among the 55 nations of the Americas (see Appendix I). At the same time, a sizable majority of these nations share features that make them ripe for comparative analyses along the dimensions of inquiry suggested here: inequality, particularly as it relates to race and class. All of these nations were founded on a history of European imperialism and settler colonialism that ravaged indigenous populations beginning in the fifteenth century (Jennings 1975; Todorov 1984). The majority of these nations also participated in the transatlantic slave trade that brought upwards of 12 million Africans to the western hemisphere between 1525 and 1866 (Eltis 2000; Eltis and Richardson 2010). Both the early economic growth of these nations and the expansion of their European populations through immigration are traceable to their participation in the transatlantic slave trade and the exploitation of African labor during their colonial eras (Drescher 1977; Eltis 1987; Williams 1944). At some point in their histories, almost all of the nations of the Americas have used ethnic and racial differences and/ or socioeconomic status to confer citizenship rights on an unequal basis (Andrews 2004; Telles et al. 2014). By the end of the twentieth century, nearly all of these nations had experienced some form of democratic transition that, in name at least, institutionalized the principle of equal citizenship. At the same time, many nations in the hemisphere had implemented various types of social welfare and poverty-reduction programs, as well as (in some cases) public policies aimed at reducing racial and ethnic disparities. Despite these changes in conferring citizenship status and legal rights, widespread disparities remain on most indicators of socioeconomic wellbeing, service provision, basic safety, and political influence along racial, ethnic, and class lines. The chapters in this report document these gaps and explore the causes of their persistence.

The work of the task force unfolded in a period in which political science has begun to pay greater attention to the causes and

APSA is pleased to include this executive summary in $P S$ in both English and Spanish. Both versions will be freely available for download and distribution. The full report is available online at www.apsanet.org/inequalities. consequences of various forms of inequality (Bartels 2009; Chalmers et al. 2003; Gilens 2013; Jacobs and Skocpol 2005). To some extent, political science has lagged behind cognate fields of history, economics, and sociology in terms of scholarly attentiveness to inequality. The recent literature on inequality in political science, however, has focused almost exclusively on rising income inequality and how it affects political representation. The long-standing gaps in the life chances of whites and communities of color in the nations of the Americas have been largely unexplored. At the same time, in Latin America, which had long denied the existence of a relationship between race and ethnicity and class disparities, there has been an explosion in data-gathering on race and ethnicity and in particular on the relationship between race and inequality (see, for example, Telles et al. 2014). The chapters developed by the task force members have explicitly sought to grapple with both the problem of rising socioeconomic inequality and the multifaceted racial gaps that exist throughout the Americas. Moreover, most of the chapters examine the ways in which race and class inequalities are epiphenomena of politics. Thus, the chapters are organized around several core concepts and theoretical insights that animate research programs in political science-e.g., the role of institutions; the mobilizing power of group memberships; party politics; and social movements.

The chapters in this report make several contributions to our understanding of racial and class inequalities in the Americas. First, the contributors share a broad agreement that the class and race inequalities that persist in the Americas are deeply rooted historically. They also agree that racial and class inequalities in the hemisphere are typically mutually constitutive. In other words, the disparities in the socioeconomic indicators that governments and social scientists often use to evaluate the life chances of individuals-e.g., income, wealth, and access to basic services-tend to map onto racially demarcated group boundaries in the Americas. The contributors also demonstrate that a multiplicity of strategies to combat racial and class inequalities have emerged in the Americas over the past 30 years and achieved varying degrees of success. In short, no regional model for combating race and class inequalities rivals the regional pacts on trade and clean energy that many of these nations began to embrace in the early 200os. In addition, many of the contributors identify important gaps in the way political science has traditionally approached the study of these questions. In particular, some of the task force contributors suggest that analyses of inequality in political science focus only on certain dimensions of state action (such as political behavior or voting) while ignoring others where the bulk of citizens, particularly communities of color, experience key disparities shaped by race and class, such as the welfare state, the criminal justice system, and the provision of public goods and services. Many of the contributors also raise questions about the type of data that is available on racial and class disparities, which 
varies significantly across the Americas, and which shapes the kinds of questions scholars are able to answer.

\section{THE STATE, RACIAL CLASSIFICATION, AND SOCIAL WELFARE}

The important role played by states in shaping political and economic life in modern nations has come into greater focus within political science since the middle decades of the twentieth century (Geddes 1994; Simon 1965; Evans et al. 1985). For scholars interested in the study of the relationship between politics and the socioeconomic and racial inequalities that exist in the Americas, two dimensions of state action have garnered considerable attention in the literature. First, the role that administrative states play in sorting human beings into categories for the distribution of citizenship rights, governmental benefits, and labor market opportunities is pivotal (Katznelson 2005; Kim 1999; Lieberman 2001; Marx 1998; Omi and Winant 1994; Smith 1997; Williams 2003). The second dimension is the overall design and performance of the welfare programs aimed at reducing inequalities (Esping-Andersen 1990; Hacker 2002; Hacker 2008). The task force members devote serious consideration to both of these issues. of a "model minority" within the racial order. Despite this valorization, Junn and Lee point out that Asian Americans continue to face discrimination and underrepresentation in a number of fields in American life. These empirical realities debunk arguments that portray racial gaps between whites and people of color in the United States as simply epiphenomena of socioeconomic status. Finally, Junn and Lee show how the "model minority" narrative obscures the rampant inequalities that exist between different ethnic subgroups.

Task force members, however, are less certain about the extent to which these modern inequalities are the path-dependent effects of the establishment of racial classifications and hierarchies in the founding moments of the 55 nations. Evidence from the United States-which had the most well-developed and punitive legal regimes governing group position in the Americas-clearly illustrates that race over-determined class status for the groups clustered at the bottom of the social hierarchy until at least the middle of the twentieth century (Allen and Farley 1986; Willie 1978; Willie 1989; Wilson 1978, 1-62). By contrast, racial categorization was more fluid in Latin America, even as racial hierarchies continued to exist (Hernández 2012; Telles 2004; Wade 1997). The literature on Latin America suggests that even during the height of the slave system in

\section{... hierarchies established in the colonial eras of most of these nations-which privileged those of European descent over indigenous populations, African slaves, and nonwhite immigrants-continue to cast a long shadow over the life chances of people of color in the western hemisphere.}

There was broad consensus within the task force that the ethnoracial hierarchies established in the colonial eras of most of these nations-which privileged those of European descent over indigenous populations, African slaves, and nonwhite immigrants-continue to cast a long shadow over the life chances of people of color in the western hemisphere. For example, Guillermo Trejo's and Melina Altamirano's chapter, "The Mexican Color Hierarchy: How Race and Skin Tone Still Define Life Chances 200 Years after Independence," shows that indigenous populations and mestizos with indigenous phenotypical features continue to experience the harshest levels of social and economic discrimination in Mexico. Trejo's and Altamirano's findings are sobering because they show that dark-brown Mexicans with indigenous features systematically report to have less access to private and public goods and services than white Mexicans and that these forms of discrimination persist at all levels of education and income. Michael Dawson's and Megan Francis's chapter, "Black Blues: The Persistence of Racialized Economic Inequality in Black Communities," also draws a bright yellow line connecting the socioeconomic inequalities and depredations that African Americans experience in the "Age of Obama" to their historical status as a subordinate group in America's racial hierarchy. Thus, as scholars of wealth acquisition and educational attainment in economics have highlighted recently (Oliver and Shapiro 2006; Shapiro 2003), intergenerational effects undoubtedly play some role in structuring the inequalities experienced by ethnoracial minorities in the Americas.

Jane Junn and Taeku Lee explore the ways in which Asian Americans continue to suffer from racist constructions of their panethnic and subgroup identities in their chapter, "Asians in the Americas." They discuss how the social meanings attached to the category "Asian" have shifted in the United States from a designation that foreclosed opportunities for full citizenship to a valorized position nations like Brazil and Colombia, opportunities for class mobility, while extremely difficult, were not completely restricted (Andrews 2004; de la Fuente 2001).

Nonetheless, as Mara Loveman's chapter, "New Data, New Knowledge, New Politics: Race, Color, and Class Inequality in Latin America," describes, newly available data reveal clear evidence of racial, ethnic, and color stratification throughout Latin America today. In many countries in the region, the very existence of these data represents a major political development, breaking with decades of official refusals to collect ethnic or racial statistics in national surveys. Social scientists are using these new data to produce a steady stream of research documenting significant inequalities by race and color. The new data are not only producing new knowledge; they are also producing new sites and stakes of political struggle over recognition, rights, and redress.

Mala Htun's chapter, "Emergence of an Organized Politics of Race in Latin America," raises concerns about the new politics of race in Latin America. She discusses potential unintended consequences of the push by Afro-descendant and indigenous groups in Brazil and Colombia to force the state to recognize (and affirmatively redress, via targeted policies) the connections between the material inequalities that shape their daily lives in the present, and the ethnoracial hierarchies that were constructed in the colonial and post-independence eras. For both Htun and Loveman, these moves portend the rise of white backlash movements in these countries and threaten important race-neutral efforts to address poverty that have recently swept through Latin America (Hall 2006; Lomeli 2008; Soares et al. 2010). We revisit the question of the extent to which the emergence of a racialized politics in Latin America foments or alleviates inequalities when we discuss Tianna Paschel's chapter, "Beyond Race or Class: Entangled Inequalities in Latin America," 
on the black consciousness movements in Brazil and Colombia in subsequent sections of this report. Given the historical trajectory of welfare states in the western hemisphere, it is reasonable to hypothesize that the rise of white backlash politics in Latin America might lead to retrenchments in the region's welfare states. After all, scholars of American politics have long pointed to the ways in which white backlash movements have generated incentives for politicians to attack the modern welfare state (Hancock 2004; Neubeck and Cazenave 2001; Quadagno 1994; Soss et al. 2001).

Comparative scholarship on inequality has also highlighted the importance of the overall design and performance of welfare states in their roles as vehicles for reducing poverty (Duncan et al. 1995; Kenworthy 1999; McFate et al. 1995). The concerns that Htun and Loveman express about the rise of efforts to address racial inequality via race-conscious policies in Latin America are derived from the fact that the subregion's relatively new welfare states have performed very well in their central task of reducing poverty. By contrast, the modern US welfare state has been bifurcated from its inception in the New Deal era, and performed very well at reducing poverty for those classified as white, while leaving behind those excluded by the color-caste system that reigned in the United States until the late twentieth century (Fox 2012; Katznelson 2005; Williams 2003). In the US context, the notion of a race-neutral welfare state is nothing more than a thought experiment. Moreover, one of the fundamental challenges for combatting rising inequality in the United States by expanding welfare provision is the tendency of white voters to ignore the transfers that have flowed to their families for generations, while simultaneously demonizing the state for attempting to equalize access to minorities under the various Great Society programs (Brown et al. 2003; Gilens 1999; Katznelson 2005; Mettler 2010).

In their chapter, "Learning from Ferguson: Welfare, Criminal Justice, and the Political Science of Race and Class," Soss and Weaver persuasively argue that racist narratives of the US welfare state have stigmatized underserved communities of color-which they term race-class-subjugated (RCS) communities-beyond simply limiting their access to social provision aimed at reducing poverty. For Soss and Weaver, these racialized narratives of welfare provision construct "public understandings" of communities of color being outside of the commonwealth. In their view, these narratives leave RCS communities vulnerable to depredations such as the "povertytrap," broken-windows style of policing that the US Department of Justice recently condemned in a report on Ferguson, Missouri. In short, Soss and Weaver assert that the exclusion of RCS communities from the welfare state is the antecedent factor in the denial of equal citizenship rights and fair treatment from other US institutions that exercise state power.

Banting's and Thompson's provocative chapter, "The Puzzling Persistence of Racial Inequality in Canada," provides a cautionary tale to all of Canada's southern neighbors seeking to use their welfare states to close socioeconomic gaps between ethnoracial groups. In the late twentieth century, Canada achieved global recognition for developing policy regimes to grapple with the nation's history of abuse and discrimination toward aboriginal peoples, adopting colorblind immigration laws and fostering multicultural tolerance. Despite these advantages, Banting and Thompson highlight a stubborn persistence of socioeconomic gaps between ethnoracial minorities and whites in Canada. Existing disparities were exacerbated by the retrenchment of Canada's welfare state, which took place primarily in the late 1980s and 1990s. This time was precisely when changes in immigration policies led to record numbers of immigrants of color coming from developing countries, and those immigrants were facing greater problems moving into the labor market, despite having higher educational credentials than previous cohorts of immigrants. In addition, an institutional quagmire in which neither the federal government nor the provinces have taken responsibility for creating effective social policies for Canada's indigenous peoples has worked to solidify the significant socioeconomic disparities between Aboriginal and non-Aboriginal Canadians. Banting and Thompson argue that rebuilding universal redistributive programs alongside race-targeted antidiscrimination policies would help remedy these ethnoracial gaps between whites and peoples of color in Canada.

\section{ATTITUDES, GROUP CONSCIOUSNESS, AND SOCIAL MOVEMENTS}

The study of attitudes about ethnic and racial group differences has been a key component of social science research since the rise of survey and experimental research techniques in the early twentieth century (Allport 1954; Bogardus 1928). Most of the early work in political science focused on the determinants of the racist attitudes whites held toward African Americans in the southern United States during desegregation (Campbell 1971; Matthews and Prothro 1966; Wright 1977). In the wake of the Voting Rights Act of 1965, which completed the formal restoration of citizenship rights to African Americans in the South, political scientists shifted their attention to understanding the determinants of white racial attitudes across the nation (Bobo 1988; Giles and Hertz 1994; Schuman et al. 1985). These studies confirm V.O. Key's (1949) "racial threat" thesis, which holds that whites tend to view African Americans as a threat to their privileged group position and interests within the polity, particularly, the relationship Key elaborated between spatial concentration of African Americans in the environment and the development of white racist attitudes.

Given that labor market outcomes, housing quality, educational opportunities, and welfare state provisions all tracked with racial group membership during the United States' long history as a Herrenvolk democracy, white Americans' tendency to see the mere presence of African Americans in their vicinity as a threat caused great consternation among social scientists. Indeed, even before the legislative victories of the Civil Rights Movement were consolidated, social scientists began examining the conditions that might lead whites to soften their negative predispositions toward African Americans (Allport 1954; Deutsch and Collins 1951; Myrdal 1944). The contact thesis-the view that sustained, noncompetitive social interactions with African Americans could moderate white racism-emerged from these early studies as the best hope for the United States to forge a healthy multiracial democracy (Aberbach and Walker 1973; Meer and Freedman 1966; Sigelman and Welch 1993; Wilner et al. 1955).

By the 1980s, support for the contact thesis had declined markedly among social scientists for several reasons. First, there is considerable evidence that whites see race relations through the lens of, what sociologist Herbert Blumer (1958) called, "group position," rather than their own personal experiences with African Americans. Thus, whites who have positive contacts with African American cohorts do not tend to translate that affective position to views of the larger group or policies designed to close the persistent racial gaps that differentiate white and black life chances in the United States (Jackman and Crane 1986). Second, given the nature of racial segregation in the United States (Iceland and Weinberg 2002; Massey and Denton 1993), the possibility that racism could be reduced by sustained social interactions between whites and African Americans is highly 
unlikely. Finally, the most robust findings about attitude change among whites occur when they form sustained relationships with African Americans who have obtained a higher socioeconomic status than theirs (Jackman and Crane 1986). Again, given the persistent racial gaps in income and wealth between whites and African Americans, these are the types of contacts that whites seldom experience.

The twentieth century closed with a bleak assessment from social science research about white racial attitudes. While several studies reported moderation of overtly racist attitudes among whites in the United States (Firebaugh and Davis 1988; Steeh and Schuman 1992; Taylor et al. 1978;), they continue to express widespread skepticism about policies designed to close the racial gaps that are the result of the systemic exclusion of African Americans during the Herrenvolk phase of American history (Bobo et al. 1997; Kinder and Sanders 1996; Kinder and Sears 1981). Recent studies have also shown that whites are increasingly seeing Latinos and Asian Americans through the lens of a "racial threat" to their group position due to the demographic shifts in the United States as a result of immigration (Bobo and Hutchings 1996; Hood and Morris 1997; Maddux et al. 2008; Rocha and Espino 2009; Tolbert and Grummel 2003). Finally some evidence exists that president Barack Obama's historic victory in markets in the region. In Brazil, for example, significant income disparities exist between whites and nonwhites with similar levels of education and experience (do Valle Silva 2000; Lovell 1994; Sanchez and Bryan 2003). Despite these facts, little attention has been given to the role that socioeconomic context plays in the formation of white racial attitudes in Latin America. Perhaps this is because Latin America's supposedly greater variety of ethnic and racial categories and the often fluid borders between them has made it difficult for many researchers to see whites in Latin Americas as occupying the same hegemonic group position that they do in the United States and Canada (Portes 1984; Wade 1997). As comparative studies of the census have shown, however, the United States has also used multiple racial classifications despite its supposedly binary racial order based on the one-drop rule (Nobles 200o). Recent public opinion studies reveal burgeoning resentment to social policies designed to upgrade the status of indigenous and Afro-descendant populations and that those individuals who identify as white in Latin America have developed a racialized group consciousness and competitive frame for viewing race relations (Bailey et al. 2015; Htun 2004). In light of these findings, the environmental determinants of white racial attitudes in Latin America can no longer be ignored.

\section{The twentieth century closed with a bleak assessment from social science research about white racial attitudes.}

2008 has promoted a spike in "old-fashioned racism," whereby white respondents are more likely to express antipathy toward African Americans in terms that resemble southern opposition to black equality during earlier periods (Tesler 2013).

During the past 20 years, political scientists have made considerable progress modeling the environmental determinants of white racial attitudes in the United States (Branton and Jones 2005; Huckfeldt and Kohfeld 1989; Oliver and Mendelberg 2000; Oliver and Wong 2003). Socioeconomic class has figured quite prominently in these models. Oliver and Mendelberg (2000), for example, demonstrated that whites living in "low-status contexts" have a greater likelihood of becoming hostile toward racial minorities and policies that target them irrespective of actual interracial competition. In other words, low-status whites are more likely to develop racist attitudes regardless of their level of exposure to minorities.

The finding of connections between low socioeconomic status and white hostility toward racial and ethnic minorities has been replicated in Canada (Blake 2003; Pettigrew 2007). Moreover, Blake (2003) has shown that, like in the American case, low-status social contexts have a potent effect on white racial attitudes regardless of the levels of "realistic competition" that they experience in relation to ethnic and racial minorities. These findings are especially striking given that, in contrast to the United States, Canada lacks the historical legacies of a racial caste system.

As we have seen, most of the nations of Latin America developed ascriptive hierarchies that privileged European-descended populations over other ethnoracial groups at some point. As Trejo and Altamirano have shown in their chapter, these European-descended populations in Mexico continue to receive greater access to basic services, such as clean water and education, than their darker-skinned co-nationals. Moreover, their evidence shows that there is no "whitening" effect-that is, the service gap between whites and dark-brown Mexicans persists at all levels of wealth and income. Similarly, there is evidence of active racial discrimination against nonwhites in labor
In the shadow of the Great Recession, which was a global economic crisis (Bagliano and Morana 2012; Llaudes et al. 2010), political scientists need to examine the relationship between socioeconomic class and white racial attitudes in the United States, Canada, and Latin America. In both the United States and Canada, whites will remain the demographic majority for several more decades into this century. As several members of the task force highlight, this means that the beliefs, fears, and attitudes of whites will continue to have a disproportionate impact on political dynamics and social policy in these nations for the foreseeable future.

It is also important that political scientists diversify their approach to conceptualizing socioeconomic standing. As we have seen, most previous research has used the level of educational attainment as a proxy for socioeconomic status in modeling the relationship between low status and racist attitudes among whites. In light of the flattening of incomes outside of the top $1 \%$ in the United States, the shrinking welfare state in Canada, and economic slowdowns in Latin America, political scientists should consider how such reversals contribute to the environment in which public opinions about race and class are formed.

Vincent Hutchings's chapter, "Public Opinion and Inequality in the United States," works through some of these questions by examining attitudes toward egalitarianism among white, black, and Latino Americans in the wake of the global financial crisis of 2008. Using data from the 2012 American National Election Study (ANES), Hutchings finds that whites have the lowest commitments to the general principle of egalitarianism among the three racial groups in the study. Moreover, Hutchings also demonstrates that whites with incomes below the national median are slightly more committed to the principle of egalitarianism than their higher-income counterparts. Given the strong bivariate relationship between education and income (Bailey and Dynarski 2011: Belley and Lochner 2007), this finding suggests that higher educational attainment may no longer moderate white racial resentment, as previous studies had identified. 
By bringing African American and Latino attitudes about egalitarianism into the equation, Hutchings builds on a robust research program examining the dynamics of racial attitude formation among minority groups in the United States in the post-civil rights era (Bobo and Hutchings 1996; Dawson 1994; Gay 2004; Gay 2006; Oliver and Wong 2003; Tate 1993). Most of these studies have found that some degree of group consciousness-rooted in past or present experiences of discrimination-is a major factor shaping the racial attitudes of African Americans and Latinos. Hutchings' main finding is that "linked-fate" is an important factor that affects the relationship between income and attitudes about egalitarianism for Latinos and African Americans. In short, the more minority groups see themselves as part of a group the more likely they are to support egalitarian policies for everyone.

The concept of group consciousness also plays an important role in several other chapters. In their chapter, "Experiencing Inequality but Not Seeing Class: An Examination of Latino Political Attitudes," Michael Jones-Correa and Sophia Wallace find that racial group consciousness generally trumps class-consciousness for Latinos in the United States. Indeed, their reanalysis of data from the ANES of 2008 and 2012 found that only about one-third of Latinos interviewed in those years viewed themselves as having a class identity. Although they do show that Latinos at higher educational and income levels
PARTIES, ELECTIONS, AND REPRESENTATION

As we have noted, democratic regimes (albeit with differing degrees of longevity, stability, and effectiveness) currently dominate the landscape of the Americas. Although a variety of constitutional forms, electoral rules, and party systems exist in the western hemisphere, two inescapable facts cut across all of these differences: people of color and the poor are underrepresented in nearly all of these nations (Carnes 2012; Cassellas 2010; Griffin and Newman 2008; Hero and Tolbert 1995; Houtzager et al. 2002; Juenke and Preuhs 2012; Luna and Zechmeister 2005; Wallace 2014). The task force examined these representation gaps across the Americas to glean insights into the factors leading to the exclusion of ethnoracial minorities and low-income citizens, as well as into the possible strategies that could be enacted to ameliorate them.

For many decades, the conventional wisdom within political science has held that individuals with low socioeconomic status participate less often in a variety of political activities than higher status individuals (Cassel and Hill 1981; Eagles 1991; Leighley and Nagler 1992; Pammett 1991; Powell 1982;Verba and Nie 1972; Wolfinger and Rosenstone 1980). Political scientists have pointed to the need to expand the participation of lower-income groups to improve their representation within political institutions across the Americas (Burnham 1987; Griffin and Newman 2005; Lijphardt

\section{... the more minority groups see themselves as part of a group the more likely they are to support egalitarian policies for everyone.}

are more likely than their counterparts to possess a "class consciousness," Latinos are less likely than whites to see their social position in class terms. As Jones-Correa and Wallace point out, this result is incredibly surprising because several studies have shown that the Great Recession hit the Latino segment of the population incredibly hard (Kochlar et al. 2011; Pew 2014). Jones-Correa and Wallace posit that the stronger attachment that Latinos show to their ethnoracial identity is because of their experiences with racialization in recent debates about immigration policy. For Jones-Correa and Wallace, Latinos' relatively weak attachment to class-consciousness in the 2008 and 2012 ANES means that it may be harder to mobilize the Latino community to support race-neutral public policies targeting economic inequality.

Jones-Correa and Wallace's findings about the Latino community dovetail with the broad perspective on social movements developed by Michael Dawson and Megan Francis in their chapter "Black Blues: The Persistence of Racialized Economic Inequality in Black Communities." That is, the Latino respondents who are the subjects of the Jones-Correa and Wallace chapter seemed to have developed an intersectional analysis of race and class that resembles the black experiences of the post-civil rights era that Dawson and Francis analyze. As Dawson and Francis explain, African Americans have long understood that the economic inequalities that they experience in the United States are part of a system of oppression based on racial difference. So, for Dawson and Francis, the Great Recession is best understood as a continuation of an assault on black lives that began in the Jim Crow era. Although they see governmental action-that is, a federal jobs program - as a way to redress this "economic racial violence," the main solution, in their view, is a social movement based on the same "black radical tradition" that fueled the end of legally encoded racial segregation in the United States in the middle of the twentieth century.
1997; Piven and Cloward 1988; Verba 2003). This view is best encapsulated by Walter Dean Burnham's famous quip, "if you don't vote [in a democracy], you don't count" $(1987,99)$.

Zoltan Hajnal and Jessica Trounstine suggest in their chapter, "Race and Class Inequalities in Local Politics," that expanding voter turnout has the potential to moderate some of the underrepresentation of minorities in urban areas of the United States. At the same time, they point out that racialized dynamics are at work in elections in US cities that will not disappear simply by raising minority turnout rates. Indeed, they find that "race is the primary driver of urban politics across most contexts" in the United States. Although there is a class skew toward high-income residents in the urban electorate, the average racial divides-between whites and African Americans, Asian Americans, and Latinos-in the vote for winning candidates "overshadows other demographic divides." They also find that despite voting at higher rates than other minorities, and over-performing expectations based on their low-socioeconomic status, African Americans are the biggest losers in urban elections on most measures. Hajnal and Trounstine further argue that African Americans' losing more often than Asian Americans and Latinos suggests that group competition exists between these minority groups, and that Asian Americans and Latinos have found it easier to form coalitions with whites and each other in urban elections. The consistent political losses of African Americans also pose a long-term problem for the health of US democracy.

Hajnal's and Trounstine's finding that there is group competition between African Americans and other minority groups at the local level is consistent with several previous studies (Kim 2003; McClain and Karnig 1990; Meier et al. 2004). For African Americans to win more frequently in urban elections, they need to forge new and more robust coalitions with Asian Americans and Latinos. Determining the barriers to the formation of these coalitions should 
be a top priority of political scientists. In other words, we need to understand how distinct group interests and or other factors, like anti-black racism, lead other groups to distance themselves from African Americans. The current literature tends to focus exclusively on the determinants of African American attitudes toward coalitions with other minorities. Gay (2004), for example, suggests that raising the socioeconomic status of African Americans could transform their perceptions of other minorities as a threat to their interests.

Examining the incentives for all groups, several recent studies have found that truly meaningful integration moderates intergroup conflict between minorities in US cities (Ha 2010; Oliver and Wong 2003; Rocha 2007; Rudolph and Popp 2010). Previous research has also shown that elite linkages can reduce conflict and facilitate coalitions between ethnoracial groups in urban areas (Bennett 1993; Browning et al. 1984; Henry and Munoz 1991; Sonenshein 1989). Although Trounstine (2010) suggests that political parties hold the potential to draw minority groups into enduring coalitions, she also notes that this potential is limited in the wake of the movement for nonpartisan government that swept US cities in the mid-twentieth century. The potential role that parties might play in closing the racial divides in American cities deserves greater attention in light economic advancement of European immigrants (Dahl 1961; Henderson 1976; Ostrogorski 1902; Schattschneider 1942). For the most part, the large urban machines did not extend the same benefits to people of color during the height of their power (Erie 1990; Grimshaw 1992; Pinderhughes 1987). Moreover, several scholars have demonstrated how in the current party system, the two major parties have often avoided courting voters of color out of deference to the racist attitudes that they believed the median voter held toward these minorities (Frymer 1999; Mendelberg 2001).

Paul Pierson's chapter, "Race, Partisanship and the Rise of Income Inequality in the United States," invokes this racial history as a partial explanation for the Republican Party's radical shift on macroeconomic policy in the post-civil rights era. Drawing on his research with Jacob Hacker (2010), Pierson argues that: "race is likely a major factor in explaining why the GOP has radicalized around economic issues, and has been able to do so in a politically sustainable way." He claims that the Republican Party's reliance on the "Southern Strategy" to gain electoral advantage in the middle decades of the twentieth century has inadvertently turned the GOP into a regional party with no incentive to compromise with the Democrats. In Pierson's view, this dynamic has freed Republican politicians to

\section{... left parties in Bolivia, Ecuador, and Peru won the allegiance for indigenous voters through a combination of direct ethnic appeals and economic populism.}

of recent evidence that the Democratic Party has been successful in "bridging black-Latino concerns" on the national level (Hero and Preuhs 2013).

Political parties have also played an important role in shaping the incorporation of ethnoracial minorities in Latin America. In his chapter, "Indigenous Voters and the Rise of the Left in Latin America," Raul Madrid demonstrates how leftist parties in the Andean region successfully realigned indigenous voters beginning in the late 1990s. Madrid shows that left parties in Bolivia, Ecuador, and Peru won the allegiance for indigenous voters through a combination of direct ethnic appeals and economic populism. He argues that this realignment was the key factor in the electoral gains that leftist parties made in Andean legislatures and some presidential elections in the late 1990 s and early 20oos. According to Madrid, one of the most striking features of the "ethnopopulist" strategies that leftist parties used in the Andean region was that they did not initially alienate nonindigenous voters. On the contrary, Madrid reports that the fusion of messages about ethnoracial and economic inequality helped the leftist parties attract voters outside of indigenous-dominated provinces as well. Finally, he points out that even when these left parties needed to pivot to more centrist messages to broaden their appeal in recent elections, they tended to maintain a focus on the inequalities faced by indigenous peoples in the Andean region. To some degree, this result is because the parties did a thorough job of integrating indigenous leaders into their organizations.

In the United States, political parties have a much more mixed history with regard to promoting the integration of ethnoracial minorities. Beginning in the Third Party System (1854-189os), the two major political parties began to aggressively compete for the votes of European immigrants streaming into the nation's rapidly industrializing cities (Bridges 1987; Sundquist 2011). By the rise of the Fourth Party System (1896-1932), both the Democrats and Republicans had perfected "machine politics" in America's urban areas. These machines were engines for both the acculturation and embrace radically conservative economic policies geared toward further enriching the top $1 \%$. Pierson rightly points out the irony of the fact that the modal voter who patronizes the Republicans at the ballot box is among the most harmed by the party's unwillingness to compromise on macroeconomic policies. Pierson also observes that people of color, who are disproportionately clustered at the bottom of the income distribution in the United States, are doubly harmed by the rising "top-end inequality" that results from "asymmetric polarization" and the racial appeals that sustain it.

In addition, several of the task force chapters demonstrate that open party systems do not always lead to outcomes that close socioeconomic gaps between ethnoracial groups, nor do they moderate income inequalities. The situation that Banting and Thompson describe in their chapter, "The Puzzling Persistence of Racial Inequality in Canada," is instructive. According to Banting and Thompson, Canada's current political parties have embraced the legacies of the "liberal ideologies" that informed the creation of that nation's expansive welfare state in the 196os and its multicultural policies. Indeed, they argue that Canadian political parties normally reject the racialized appeals that are so commonplace in the United States out of fear that they will be punished at the ballot box. The defeat of the Conservative Party in 2015-an election government in which they broke from Canadian tradition by insisting that Muslim women remove their niqabs during citizenship ceremonies and advancing a race-baiting proposal to create a Royal Canadian Mounted Police hotline for Canadians to report "barbaric cultural practices"-lends support to this hypothesis. At the same time, all of the major parties have also rejected economic populism in favor of retrenchment. In this situation, Banting and Thompson argue, the parties lack the vision and/or willingness to develop specific policies aimed at combatting the economic inequalities that track with certain racial identities. Thus, in Canada, it is impossible to fix racial inequality because the political elite has turned away from populist politics.

Paschel's chapter, "Beyond Race or Class: Entangled Inequalities 
in Latin America," highlights two other tensions between the politics of representation and public policies aimed at targeting racial and class inequalities in the Americas. Paschel notes that in both Brazil and Colombia race-conscious public policies have not dramatically improved the living standards of Afro-descendant and indigenous peoples in those nations. She argues that the progressive laws that these two countries have passed to establish group-based rights for ethnoracial minorities sometimes "do not stick" in the implementation phase. In Colombia, for example, she points out that politicians have often used the multicultural policies aimed at establishing black land rights in rural areas to advance their own favored development policies. In other words, they have coopted ethnoracial minorities, who have often lacked the ability to take advantage of these new laws, to serve their own ends. Paschel acknowledges that Brazil has done a better job than most other countries in the region in rapidly reducing their poverty rate through social welfare programs. At the same time, she notes that the "the impact of these policies on racial inequality is less clear." This outcome is because race over-determines socioeconomic status in Brazil in the same way that it does throughout the region. Thus, the $50 \%$ reduction in poverty since the initiation of the "Bolsa Familia" welfare programs is significant, but those left behind are still disproportionately Afro-descendant. One reason for these continued gaps, Paschel suggests, is that the state and society lack the capacity to fully implement the progressive racial reforms that public opinion polls indicate most Brazilians support.

All of these findings show that ethnoracial minorities, even in countries in which they represent a large percentage of the population and participate actively in elections, are hampered in translating their demographic potential and civic participation into meaningful socioeconomic gains by their low socioeconomic status and the incentives of the party system.

\section{RE F E R E N C E S}

Aberbach, Joel D., and Jack L. Walker. 1973. Race in the City: Political Trust and Public Policy in the New Urban System. Boston: Little, Brown.

Allen, Walter R., and Reynolds Farley. 1986. "The Shifting Social and Economic Tides of Black America, 1950-1960," Annual Review of Sociology 12: 277-306.

Allport, Gordon. 1954. The Nature of Prejudice. Reading, MA: Addison-Wesley.

Andrews, George Reid. 2004. Afro-Latin America, 1800-200o. New York: Oxford University Press

Bailey, Martha J., and Susan M. Dynarski. 2011. "Gains and Gaps: Changing Inequality in U.S. College Entry and Completion.” National Bureau of Economic Research Working Papers Series 17633: 1-30.

Bailey, Stanley R., Fabricio Failho, and Michelle Peria. 2015. "Support for RaceTargeted Affirmative Action in Brazil." Ethnicities o (o): 1-34.

Bagliano, Fabio, and Claudio Morana. 2012. "The Great Recession: US Dynamics and Spillovers to the World Economy." Journal of Banking and Finance 36 (1): 1-13.

Bartels, Larry. 2009. Unequal Democracy: The Political Economy of the New Gilded Age. Princeton, NJ: Princeton University Press.

Belley, Philippe, and Lance Lochner. 2007. "The Changing Role of Family Income and Ability in Determining Educational Attainment." National Bureau of Economic Research Working Papers Series 13527: 1-68.

Bennett, Larry. 1993. "Harold Washington and the Black Urban Regime." Urban Affairs Review 28 (3): 423-40.

Blake, Donald E. 2003. "Environmental Determinants of Racial Attitudes among White Canadians." Canadian Journal of Political Science 36 (3): 491-509.

Blumer, Herbert. 1958. "Race Prejudice as a Sense of Group Position." The Pacific Sociological Review 1 (1): 3-7.

Bobo, Lawrence. 1988. "Group Conflict, Prejudice, and the Paradox of Contemporary Racial Attitudes.” In Eliminating Racism: Profiles in Controversy, eds. Phyllis Katz and Dalmas Taylor. New York: Plenum Press.
Bobo, Lawrence, and Vincent Hutchings. 1996. "Perceptions of Racial Group Competition: Extending Blumer's Theory of Group Position to a Multiracial Social Context." American Sociological Review 61 (6): 951-72.

Bobo, Lawrence, James R. Kluegel, and Ryan A. Smith. 1997. "Laissez-Faire Racism: The Crystallization of a Kinder, Gentler, Antiblack Ideology.” In Racial Attitudes in the 199os: Continuity and Change, eds. Steven A. Tuch and Jack K. Martin. Westport, CT: Greenwood Press.

Bogardus, Emory S. 1928. Immigration and Race Attitudes. Boston: D.C. Heath.

Branton, Regina, and Bradford S. Jones. 2005. "Reexamining Racial Attitudes: The Conditional Relationship between Diversity and Socioeconomic Environment." American Journal of Political Science 49 (2): 359-72.

Bridges, Amy. 1987. A City in the Republic: Antebellum New York and the Origins of Machine Politics. Ithaca, NY: Cornell University Press.

Brown, Michael K., Martin Carnoy, Elliot Currie, Troy Duster, David B. Oppenheimer, Majorie M. Schultz, and David Wellman. 2003. White-Washing Race: The Myth of the Color-Blind Society. Los Angeles: University of California Press.

Browning, Rufus P., Dale Rogers Marshall, and David H. Tabb. 1984. Protest Is Not Enough: The Struggle of Blacks and Hispanics for Equality in Urban Politics. New York: Longman.

Burnham, Walter Dean. 1987. “The Turnout Problem.” In Elections American Style, ed. A James , Reichley, 97-133. Washington, DC: Brookings Institution Press.

Campbell, Angus. 1971. White Attitudes toward Black People. Ann Arbor, MI: Institute for Social Research.

Carnes, Nicholas. 2012. "Does the Numerical Underrepresentation of the Working Class in Congress Matter?" Legislative Studies Quarterly 37(February): 5-34.

.2016. "Why Are There So Few Working-Class People in Political Office? Evidence from State Legislatures.” Politics, Groups, and Identities 4 (1): 84-109.

Cassel, Carol A., and David B. Hill. 1981. "Explanations of Turnout Decline: A Multivariate Test." American Politics Quarterly 9: 191-95

Cassellas, Jason. 2010. Latino Representation in State Houses and Congress. New York: Cambridge University Press.

Chalmers, Douglas, Carlos Vilas, Katherine Hite, Scott Martin, Kerianne Piester, and Monique Segarra. 2003. The New Politics of Inequality in Latin America. New York: Oxford University Press.

Dahl, Robert. 1961. Who Governs? Democracy and Power in an American City. New Haven, CT: Yale University Press.

Dawson, Michael C. 1993. Behind the Mule: Race and Class in African-American Politics. Princeton, NJ: Princeton University Press.

de la Fuente, Alejandro. 2001. A Nation for All: Race, Inequality, and Politics in Twentieth-Century Cuba. Chapel Hill: University of North Carolina Press.

Deutsch, Morton and Mary Collins. 1951. Interracial Housing: A Psychological Evaluation of a Social Experiment. Minneapolis: University of Minnesota Press.

Drescher, Seymour. 1977. Econocide: British Slavery in the Era of Abolition. Pittsburgh, PA: University of Pittsburgh Press.

Downs, Anthony. 1957. "An Economic Theory of Political Action in Democracy." Journal of Political Economy 65 (2): 135-150.

do Valle Silva, Nelson. 200o. "A Research Note on the Cost of Not Being White in Brazil." Studies in Comparative International Development 35 (2): 18-28.

Duncan, Greg J., and Bjorn Gustafsson, Richard Hauser, Gunther Schmaus, Stephen Jenkins, Hans Messinger, Ruud Muffels, Brian Nolan, Jean-Claude Ray, and Wolfgang Voges. 1995. "Poverty and Social-Assistance Dynamics in the United States, Canada and Europe." In Poverty, Inequality and the Future of Social Policy: Western Welfare States in the New World Order, eds. Kate McFate, Roger Lawson and William Julius Wilson. New York: Russell Sage Foundation.

Eagles, Donald Munroe. 1991. "Voting and Non-Voting in Canadian Federal Elections: An Ecological Analysis." In Voter Turnout in Canada, ed., H. Bakvis. Toronto: Dundurn Press.

Eltis, David. 1987. Economic Growth and the Ending of the Transatlantic Slave Trade. New York: Oxford University Press.

Eltis, David. 2000. The Rise of African Slavery in the Americas. New York: Oxford University Press.

Eltis, David, and David Richardson. 2010. "The Transatlantic Slave Trade Database." Atlanta, GA: Emory University.

Erie, Steven. 1990. Rainbow's End: Irish Americans and the Dilemmas of UrbanMachine Politics, 1840-1985. Berkeley: University of California Press.

Esping-Andersen, Gøsta. 1990. The Three Worlds of Welfare Capitalism. Cambridge, UK: Polity Press.

Evans, Peter B., Dietrich Rueschemeyer, and Theda Skocpol. 1985. Bringing the State Back In. New York: Cambridge University Press.

Firebaugh, Glenn and Kenneth E. Davis. 1988. "Trends in Antiblack Prejudice, 1972-1984: Region and Cohort Effects." American Journal of Sociology 94 (2): 251-72 
Fox, Cybelle. 2012. Three Worlds of Relief: Race, Immigration, and the American Welfare State from the Progressive Era to the New Deal. Princeton, NJ: Princeton University Press.

Frymer, Paul. 1999. Uneasy Alliances: Race and Party Competition in America. Princeton, NJ: Princeton University Press.

Gay, Claudine. 2004. "Putting Race in Context: Identifying the Environmenta Determinants of Black Racial Attitudes.” American Political Science Review 98 (4): 547-62.

- 2006. "Seeing Difference: The Effect of Economic Disparity on Black Attitudes toward Latinos." American Journal of Political Science 50 (4): 982-97.

Geddes, Barbara. 1994. Politician's Dilemma: Building State Capacity in Latin America. Berkeley: University of California Press.

Gee, Ellen M., and Steven G. Prus. 200o. "Income Inequality in Canada: A Racial Divide." Perspectives on Ethnicity in Canada: A Reader 4: 238-56.

Gilens, Martin. 1999. Why Americans Hate Welfare: Race, Media, and the Politics of Antipoverty Policy. Chicago: University of Chicago Press.

. 2013. Affluence and Influence: Economic Inequality and Political Power in America. Princeton, NJ: Princeton University Press.

Giles, Michael and Kaenan Hertz. 1994. "Racial Threat and Partisan Identification." American Political Science Review 88: 317-26.

Griffin, John, and Brian Newman. 2005. “Are Voters Better Represented?” Journal of Politics 67 (4): 1206-227.

- 2008. Minority Report: Evaluating Political Equality in America. Chicago: University of Chicago Press.

Grimshaw, William J. 1992. Bitter Fruit: Black Politics and the Chicago Machine, 1931-1991. Chicago: University of Chicago Press.

Ha, Shang E. 2010. "The Consequences of Multiracial Contexts on Public Attitudes toward Immigration." Political Research Quarterly 63 (1): 29-42.

Hacker, Jacob. 2002. The Divided Welfare State: The Battle over Public and Private Social Benefits in the United States. New York: Cambridge University Press.

- 2008. The Great Risk Shift: The New Economic Insecurity and the Decline of the American Dream. New York: Oxford University Press.

Hacker, Jacob and Paul Pierson. 2010. "Winner-Take-All Politics: Public Policy, Political Organization, and the Precipitous Rise of Top Incomes in the United States." Politics and Society 38 (2): 152-204.

Hall, A. 2006. "From Fome Zero to Bolsa Familia: Social Policies and Poverty Alleviation under Lula." Journal of Latin American Studies 38 (4): 689-709.

Hancock, Ange-Marie. 2004. The Politics of Disgust: The Public Identity of the Welfare Queen. New York: New York University Press.

Henderson, Thomas M. 1976. Tammany Hall and the New Immigrants: The Progressive Years. Manchester, NH: Arno Press.

Henry, Charles P., and Carlos Munoz, Jr. 1991. "Ideological and Interest Linkages in California Rainbow Politics." In Racial and Ethnic Politics in California, eds. Bryan O. Jackson and Michael B. Preston, 323-38. Berkeley, California: IGS Press.

Hernández, Tanya Katerí. 2012. Racial Subordination in Latin America: The Role of the State, Customary Law, and the New Civil Rights Response. Cambridge, UK: Cambridge University Press.

Hero, Rodney. 1992. Latinos and the U.S. Political System: Two-Tiered Pluralism. Philadelphia: Temple University Press.

Hero, Rodney, and Caroline Tolbert. 1995. "Latinos and Substantive Representation in the US House of Representatives: Direct, Indirect, or Nonexistent?"American Journal of Political Science 39 (3): 640-52.

Hero, Rodney and Robert Preuhs. 2013. Black-Latino Relations in US National Politics New York: Cambridge University Press.

Hood, M.V., and Irwin L. Morris. 1997. “AAmigo O Enemigo? Context, Attitudes, and Anglo Public Opinion Towards Immigration.” Social Science Quarterly 78 (2): 309-23.

Houtzager, Peter, Ruth Berins Collier, John Harriss, and Adrian Lavalle. 2002. "Rights, Representation and the Poor: Comparisons across Latin America and India." Institute for Development Studies, Working Paper No. 02-31: 1-13.

Htun, Mala. 2004. "From 'Racial Democracy' to Affirmative Action: Changing State Policy on Race in Brazil." Latin American Research Review 39 (1): 6o-89.

Huckfeldt, Robert, and Carol Kohfeld. 1989. Race and the Decline of Class in American Politics. Urbana: University of Illinois Press.

Iceland, John, and Daniel Weinberg. 2002. Racial and Ethnic Residential Segregation in the United States, 1980-20oo. Washington, DC: US Census Bureau.

Jackman, Mary R., and Mary Crane. 1986."Some of My Best Friends are Black...”: Interracial Friendship and Whites' Racial Attitudes.” Public Opinion Quarterly $50(4): 459-86$.

Jacobs, Larry, and Theda Skocpol. 2005. Inequality and American Democracy. New York: Russell Sage Foundation.
Jennings, Francis. 1975. The Invasion of America: Indians, Colonialism, and the Cant of Conquest. Chapel Hill: University of North Carolina Press.

Juenke, Eric, and Robert Preuhs. 2012. "Irreplaceable Legislators? Rethinking Minority Representatives in the New Century." American Journal of Political Science 56 (3): 705-15.

Katznelson, Ira. 2005. When Affirmative Action was White: An Untold History ofRacial Inequality in the Twentieth Century. New York: W.W. Norton.

Kenworthy, Lane. 1999. "Do Social-Welfare Policies Reduce Poverty? A Cross-National Assessment.” Social Forces 77 (3): 1119-139.

Key, Valdimer Orlando. 1949. Southern Politics in State and Nation. New York: A.A. Knopf.

Kim, Claire J. 1999. “The Racial Triangulation of Asian Americans.” Politics and Society 27 (1): 105-138.

. 2003. Bitter Fruit: The Politics of Black-Korean Conflict in New York City. New York: Yale University Press.

Kinder, Donald R. and Lynn Sanders. 1996. Divided By Color: Racial Politics and Democratic Ideals. Chicago: University of Chicago Press.

Kinder, Donald R., and David Sears. "Prejudice and Politics: Symbolic Racism versus Racial Threats to the Good Life." Journal of Personality and Social Psychology 40 (3): 414-31.

Kolchar, Rakesh, Richard Fry, and Paul Taylor. 2011. "Wealth Gaps Rise to Record Highs between Whites, Blacks, and Hispanics.” Pew Research Center.

Leighley, Jan E., and Jonathan Nagler. 1992. "Individual and Systemic Influences on Turnout: Who Votes? 1984." Journal of Politics 54: 718-40.

Lieberman, Robert. 2001. Shifting the Color Line: Race and the American Welfare State. Cambridge, MA: Harvard University Press.

Lijphart, Arend. 1997. “Unequal Participation: Democracy’s Unresolved Dilemma, Presidential Address.” American Political Science Review 91 (01): 1-14.

Llaudes, Ricardo, Ferhan Salmon, and Mali Chivakul. 2010. "The Impact of the Great Recession on Emerging Markets." IMF Working Paper 10 (237): 1-30.

Lomeli, Enrique V. 2008. "Conditional Cash Transfers as Social Policy in Latin America: An Assessment of Their Contributions and Limitations." Annual Review of Sociology 34: 475-99.

Lovell, Peggy. 1994. "Race, Gender and Development." Latin American Research Review 29 (3): 7-35.

Luna, Jaun Pablo, and Elizabeth J. Zechmeister. 2005. "Political Representation in Latin America." Comparative Political Studies 38 (4): 388-416.

Maddux, William W., Adam D. Galinsky, Amy J.C. Cuddy, and Mark Polifroni. 2008."When Being a Model Minority is Good and Bad: Realistic Threat Explains Negativity toward Asian Americans." Personality and Social Psychology Bulletin 34 (1): $74-89$.

Marx, Anthony. 1998. Making Race and Nation: A Comparison of South Africa, the United States, and Brazil. New York: Cambridge University Press.

Massey, Douglas, and Nancy A. Denton. 1993. American Apartheid: Segregation and the Making of the Underclass. Cambridge, MA: Harvard University Press.

Matthews, Donald, and James Prothro. 1966. Negroes and the New Southern Politics. Chapel Hill: University of North Carolina Press.

Mendelberg, Tali. 2001. The Race Card: Campaign Strategy, Implicit Messages, and the Norm of Racial Equality. Princeton, NJ: Princeton University Press.

McClain, Paula D., and Albert Karnig. 1990. "Black and Hispanic Socioeconomic and Political Competition." American Political Science Review 84 (2): 535-45.

McFate, Kate, Timothy Seeding, and Lee Rainwater. 1995. "Markets and States: Poverty Trends and Transfer System Effectiveness in the 1980s." In Poverty, Inequality and the Future of Social Policy: Western Welfare States in the New World Order, eds. Kate McFate, Roger Lawson, and William Julius Wilson. New York: Russell Sage Foundation.

Meer, Bernard, and Edward Freeman. 1966. "The Impact of Negro Neighbors on White Homeowners." Social Forces 45: 11-19.

Meier, Kenneth J., Paul D. McClain, J.L. Polinard, and Robert D. Winkle. 2004 "Divided or Together? Conflict and Cooperation between African Americans and Latino." Political Research Quarterly 57 (3): 399-409.

Mettler, Suzanne. 2010. "Reconstituting the Submerged State: The Challenges of Social Policy Reform in the Obama Era." Perspectives on Politics 8 (3): 803-24.

Myrdal, Gunnar. 1944. An American Dilemma. New York: Harper and Brothers.

Neubeck, Kenneth J., and Noel A. Cazenave. 2001. Welfare Racism: Playing the Race Card Against America's Poor. New York: Routledge.

Nobles, Melissa. 200o. Shades of Citizenship: Race and the Census in Modern Politics. Redwood City, CA: Stanford University Press.

Oliver, Eric, and Tali Mendelberg. 200o. "Reconsidering the Environmental Determinants of White Racial Attitudes." American Journal of Political Science $44(3): 574-89$. 
Oliver, Eric and Janelle Wong. 2003. "Intergroup Prejudice in Multiethnic Settings." American Journal of Political Science 47 (4): 567-82.

Oliver, Melvin, and Thomas Shapiro. 2006. Black Wealth, White Wealth: A New Perspective on Racial Inequality. New York: Routledge.

Omi, Michael and Howard Winant. 1994. Racial Formation in the United States: From the 1960 s to the 199os. New York: Routledge.

Ostrogorski, Moisei. 1902. Democracy and the Organization of Political Parties. New York: Macmillan and Company.

Pammet, Jon H. 1991. "Voting Turnout in Canada," In Voter Turnout in Canada, ed. H. Bakis. Toronto: Dundurn Press.

Pettigrew, Thomas F. 1957. "Desegregation and Its Chances for Success: Northern and Southern Views." Social Forces 35 (4): 339-44.

Pettigrew, Thomas F. 2007. “Who Opposes Immigration?” Du Bois Review: Social Science Research on Race 4 (1): 19-39.

Pew Research Center. 2014. "Wealth Inequality Has Widened Along Racial/Ethnic Lines Since the End of the Great Recession." Washington, DC: Pew Charitable Trusts.

Pinderhughes, Dianne. 1987. Race and Ethnicity in Chicago Politics: A Reexamination of Pluralist Theory. Urbana: University of Illinois Press.

Piven, Frances Fox, and Richard A. Cloward. 1988. Why Americans Don't Vote. New York: Pantheon Press.

Portes, Alejandro. 1984. "The Rise of Ethnicity: Determinants of Ethnic Perceptions among Cuban Exiles in Miami." American Sociological Review 49 (3): 383-97.

Powell, G. Bingham. 1982. Comparative Democracies: Participation, Stability and Violence. Cambridge, MA: Harvard University Press.

Quadagno, Jill. 1994. The Color of Welfare: How Racism Undermined the War on Poverty. New York: Oxford University Press.

Rocha, Rene R. 2007. "Black-Brown Coalitions in Local School Board Elections." Political Research Quarterly 6o (2): 315-27.

Rocha, Rene R., and Rodolfo Espino. 2009. "Racial Threat, Residential Segregation, and the Policy Attitudes of Anglos." Political Research Quarterly 62 (2): 415-26.

Rudolph, Thomas J., and Elizabeth Popp. 2010. "Race, Environment and Interracial Trust." Journal of Politics 72 (1): 74-89.

Sanchez, Margarita, and Maurice Bryan. 2003. "Afro-Descendants, and Discrimination Economic Exclusion in Latin America." London: Minority Rights Group International.

Schattschneider, Elmer Eric. 1942. Party Government. New Brunswick, NJ: Transaction Publishers.

Schuman, Howard, Charles Steeh, and Lawrence Bobo. 1985. Racial Attitudes in America: Trends and Interpretations. Cambridge, MA: Harvard University Press.

Sigelman, Lee, and Susan Welch. 1993. "The Contact Hypothesis Revisited: BlackWhite Interaction and Positive Racial Attitudes." Social Forces 71 (3): 781-95.

Simon. Herbert. 1965. Administrative Behavior. New York: Cambridge University Press.

Shapiro, Thomas. 2003. The Hidden Cost of Being African American: How Wealth Perpetuates Inequality. New York: Oxford University Press.

Smith, Rogers. 1997. Civic Ideals: Conflicting Visions of Citizenship in U.S. History. New Haven, CT: Yale University Press.

Soares, Fabio V.S., Rafael Ribas, and Rafael Osorio. 2010. "Evaluating the Impact of Brazil's Bolsa Familia: Cash Transfer Programs in Comparative Perspective." Latin American Research Review 45 (2): 173-90.
Sonenshein, Raphael J. 1989. "The Dynamics of Biracial Coalitions: Crossover Politics in Los Angeles." The Western Political Quarterly 42 (2): 333-53.

Soss, Joe, Sanford F. Schram, Thomas P. Vartanian, and Erin O'Brien. 2001."Setting the Terms of Relief: Explaining State Policy Choices in the Devolution Revolution." American Journal of Political Science 45 (2): 378-95.

Steeh, Charles, and Howard Schuman. 1992. "Young White Adults: Did Racial Attitudes Change in the 1980s?" American Journal of Sociology 98 (2): 340-67.

Sundquist, James L. 2011. Dynamics of the Party System: Alignment and Realignment of Political Parties in the United States. Washington, DC: Brookings Institution Press.

Tate, Katherine. 1993. From Protest to Politics: The New Black Voters in American Elections. Cambridge, MA: Harvard University Press.

Taylor, D.G., P.B. Sheatsley, and A.M. Greeley. 1978. "Attitudes toward Racial Integration." Scientific American 238 (6): 42-49.

Telles, Edward E. 2004. Race in Another America: The Significance of Skin Color in Brazil. Princeton, NJ: Princeton University Press.

_. 1994. "Industrialization and Racial Inequality in Employment: The Brazilian Example." American Sociological Review 59 (September); 46-63.

Telles, Edward, and Project on Ethnicity and Race in Latin America. 2014 Pigmentocracies: Ethnicity, Race, and Color in Latin America. Chapel Hill: University of North Carolina Press.

Tesler, Michael. 2013. "The Return of Old-Fashioned Racism to White Americans' Partisan Preferences in the Early Obama Era." Journal of Politics 75 (1): 110-23.

Todorov, Tzevtan. 1984. The Conquest of America: The Question of the Other. New York: Harper and Row.

Tolbert, Caroline J., and John A. Grummel. 2003. "Revisiting the Racial Threat Hypothesis: White Voter Support for California's Proposition 209." State Politics and Policy Quarterly 3 (2): 183-202.

Trounstine, Jessica. 2010. "Representation and Accountability in Cities." Annua Review of Political Science 13: 407-23.

Verba, Sidney. 2003. "Would the Dream of Political Equality Turn out to Be a Nightmare?" Perspectives on Politics 1 (4): 663-79.

Verba, Sidney, and Norman Nie. 1972. Participation in America: Political Democracy and Social Equality. New York: Harper and Row.

Wade, Peter. 1997. Race and Ethnicity in Latin America. London: Pluto Press.

Wallace, Sophia. 2014. "Examining Latino Support for Descriptive Representation: The Role of Identity and Discrimination." Social Science Quarterly 95 (2): 311-27

Willie, Charles V. 1978. “The Inclining Significance of Race," Society 15 (5): 10.

. 1989. The Caste and Class Controversy on Race: Round Two of the Willie/Wilson Debate. Lanham, MD: Roman and Littlefield.

Williams, Eric. 1944. Capitalism and Slavery. Chapel Hill: University of North Carolina.

Williams, Linda F. 2003. The Constraint of Race: Legacies of White Skin Privilege in America. State College: Pennsylvania State University Press.

Wilner, Daniel, Rosebelle Walkley, and Stuart Cook. 1955. Human Relations in Interracial Housing. Minneapolis: University of Minnesota Press.

Wilson, William J. 1978. The Declining Significance of Race: Blacks and Changing American Institutions. Chicago: University of Chicago Press.

Wolfinger, Raymond E., and Stephen J. Rosenstone. 1980. Who Votes? New Haven, CT: Yale University Press.

Wright, Gerald C. 1977. "Contextual Models of Electoral Behavior: The Southern Wallace Vote," American Political Science Review 71 (2): 497-508. 


\section{Appendix}

\section{COUNTRIES OF NORTH AND SOUTH AMERICA}

Anguilla (UK)

Antigua and Barbuda

Argentina

Aruba (Kingdom of the Netherlands)

Barbados

Belize

Bermuda (UK)

Bolivia

Brazil

British Virgin Islands (UK)

Canada

Caribbean Netherlands (Kingdom of the

Netherlands)

Cayman Islands (UK)

Chile

Colombia

Costa Rica

Cuba

Curaçao (Kingdom of the Netherlands)

Dominica

Dominican Republic

Ecuador

El Salvador

Falkland Islands

French Guiana

Greenland (Denmark)

Grenada

Guadeloupe (France)

Guatemala

Guyana

Haiti

Honduras

Jamaica

Martinique (France)

Mexico

Montserrat (UK)

Nicaragua

Panama

Paraguay

Peru

Puerto Rico (US)

Saint Barthélemy (France)

Saint Kitts and Nevis

Saint Lucia

Saint Martin (France)

Saint Pierre and Miquelon (France)

Saint Vincent and the Grenadines

Sint Maarten (Kingdom of the Netherlands)

Suriname

The Bahamas

Trinidad and Tobago

Turks and Caicos Islands (UK)

United States

United States Virgin Islands (US)

Uruguay

Venezuela

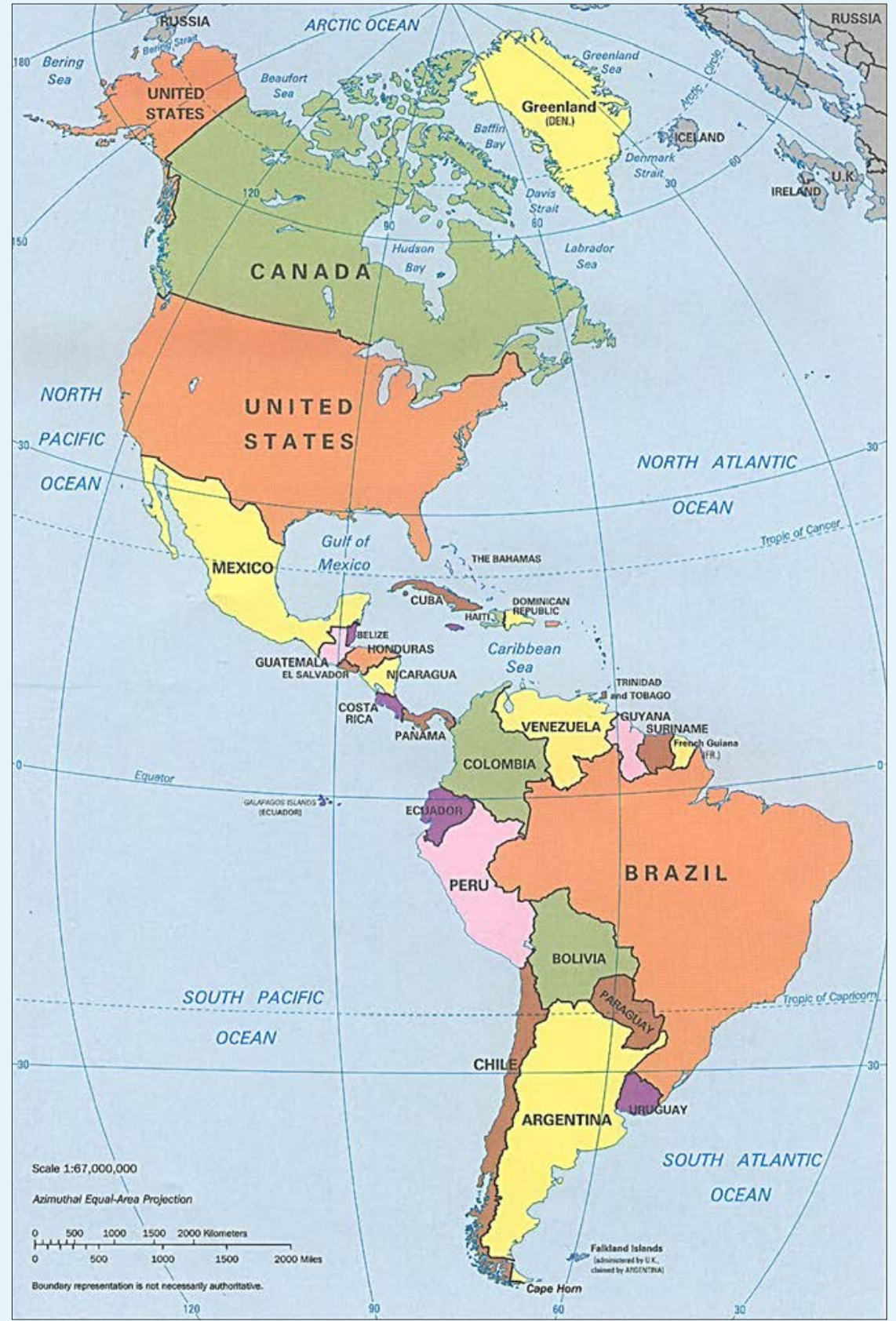

